\title{
Analisis Faktor yang Memengaruhi Niat Penggunaan Sistem Informasi Akuntansi
}

\author{
Anak Agung Dwi Kristiyanthi ${ }^{1}$ \\ Fakultas Ekonomi dan Bisnis \\ Universitas Udayana, Indonesia. \\ Email: gungwik23@gmail.com
}

\author{
Ida Bagus Dharmadiaksa2 \\ Fakultas Ekonomi dan Bisnis \\ Universitas Udayana, Indonesia.
}

\begin{abstract}
ABSTRAK
Bank BPD Bali turut berperan dalam menggerakan perekonomian daerah khususnya di Provinsi Bali dengan mendukung pembiayaan pembangunan di daerah termasuk pelayanan Usaha Mikro Kecil Menengah. Namun, terdapat beberapa kendala dalam penerapan sistem tersebut diantaranya waktu yang terbatas dalam menyelesaikan pekerjaan, kompleksnya fitur sistem terkini sehingga kurang dikuasai karyawan dan pengalaman yang masih kurang memadai. Jumlah sampel dalam penelitian ini adalah sebanyak 51 orang. Penelitian ini menemukan bahwa personalisasi dan daya tarik alternatif berpengaruh positif terhadap persepsi kegunaan, daya tarik alternatif berpengaruh positif terhadap persepsi kemudahan penggunaan, personalisasi tidak berpengaruh terhadap persepsi kemudahan penggunaan dan pengalaman pengguna sistem tidak berpengaruh terhadap keduanya. Kemudian persepsi kegunaan berpengaruh positif terhadap niat untuk tetap menggunakan, namun tidak berpengaruh bagi persepsi kemudahan penggunaan.
\end{abstract}

Kata Kunci :

Personalisasi; Daya Tarik Alternatif; Pengalaman Pengguna Sistem; SIA.

\section{Analysis of Factors That Influence Intention of Using Accounting Information Systems}

\section{ABSTRACT}

Bank BPD Bali also play a role in driving the regional economy, especially in the Province of Bali by supporting development funding in the regions, including the service of Micro, Small and Medium Enterprises. However, there are several obstacles in implementing the system including limited time in completing work, the complexity of the latest system features so that employees are less controlled and experience is still inadequate. The number of samples in this study were 51 people. This study found that personalization and alternative attractiveness had a positive effect on perceived usefulness, alternative attractiveness had a positive effect on perceived ease of use, personalization had no effect on perceived ease of use and system user experience had no effect on both. Then the perception of usefulness has a positive effect on the intention to keep using, but does not affect the perception of ease of use.

Keywords: $\quad$ Personalization; Alternative Attractiveness; System User Experience; SIA.

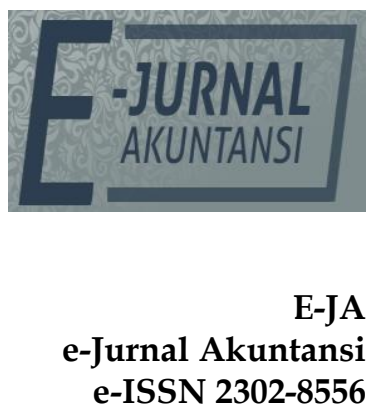

Vol. 29 No. 3

Denpasar, Desember

2019

Hal. 1166-1180

Artikel masuk: 25 September 2019

Tanggal diterima: 17 Desember 2019 


\section{PENDAHULUAN}

Penggunaan sistem informasi khususnya sistem informasi akuntansi telah dikembangkan dan diberikan perhatian khusus oleh kebanyakan perusahaan ataupun instansi tertentu di dunia. Dengan demikian, untuk pengguna sistem informasi akuntansi pada sektor keuangan ataupun bisnis tentunya selalu berusaha melakukan berbagai cara untuk menggembangkan sistem informasi yang digunakan. Hal tersebut disebabkan karena sistem informasi akuntansi memegang peranan yang cukup penting untuk mendukung operasi bisnis, mendukung pengambilan keputusan serta medukung keunggulan strategis.

Technology Acceptance Model (TAM) didefinisikan oleh Davis (1986) sebagai salah satu model yang dibangun untuk menganalisis dan memahami faktor- faktor yang mempengaruhi diterimanya penggunaan teknologi komputer. Sejak diperkenalkannya Technology Acceptance Model (TAM) oleh Davis, banyak peneliti yang mencoba menerapkan TAM ke penelitian-penelitian empiris baik untuk menguji teorinya maupun untuk menjelaskan fenomena yang akan diteliti (Hartono, 2014).

Davis (1989) menyatakan bahwa tingkat penerimaan penggunaan TI ditentukan oleh lima konstruk yaitu, variabel eksternal (external variable), persepsi kegunaan (perceived usefulness) dan persepsi kemudahaan (perceived ease of use), sikap dalam menggunakan (attitude toward using), niat untuk menggunakan (behavioral intention to use), dan kondisi nyata penggunaan sistem (actual system usage).

Teori TAM menyatakan bahwa terdapat dua keyakinan variabel perilaku utama yang pada dasarnya dipengaruhi oleh variabel eksternal dalam mengadopsi sistem informasi. Adapun dua variabel tersebut yaitu persepsi kegunaan (perceived usefulness) dan persepsi kemudahan penggunaan (perceived ease of use). Persepsi kegunaan adalah faktor yang banyak digunakan dalam proses adopsi sistem informasi dan didefinisikan sebagai sejauh mana pengguna sistem menggunakan teknologi atau sistem informasi maka akan dapat meningkatkan efisiensi kerja pengguna tersebut ( $\mathrm{Hu}$, Ding, $\mathrm{Li}$, Chen, \& Yang, 2019). Selanjutnya Doll Et al., (1998) dalam Devi \& Suartana (2014) mengartikan persepsi kegunaan sebagai tingkat dimana seseorang yakin bahwa penggunaan sistem akan membantunya dalam meningkatkan kinerja dalam konteks organisasi. Persepsi kemudahan penggunaan didefinisikan sebagai sebagai tingkat kemudahan penggunaan sistem yang akan dapat mengurangi usaha seseorang dalam menyelesaikan pekerjaannya.

Sektor perbankan merupakan salah satu contoh organisasi yang menerapkan SIA dalam operasionalnya karena dianggap penting untuk membantu perusahaan dalam menyusun laporan keuangannya dan kemudian menginformasikan kepada para nasabah ataupun pemangku kepentingan lainnya. Menurut pasal 1 Undang-Undang No. 10 Tahun 1998, bank merupakan badan usaha yang menghimpun dana dari masyarakat dalam bentuk simpanan dan penyaluranya ke masyarakat dalam bentuk kredit dan/atau dalam bentuk lainnya dalam rangka meningkatkan taraf hidup masyarakat banyak.

Bank Pembangunan Daerah (BPD) merupakan salah satu kelompok lembaga keuangan yang turut berperan dalam menggerakan perekonomian daerah khususnya di Provinsi Bali dengan mendukung pembiayaan 
pembangunan di daerah termasuk pelayanan Usaha Mikro Kecil Menengah (UMKM). PT. Bank Pembangunan Daerah Bali atau disebut Bank BPD Bali adalah sebuah perseroan yang diharapkan dapat memanfaatkan perkembangan teknologi untuk meningkatkan kinerja dan pelayanannya, agar visi dan misi bisa terlaksana dengan baik. Salah satu caranya yaitu dengan menerapkan sistem informasi akuntansi untuk meningkatkan pengendalian internal Bank, sehingga dalam pelaporannya dapat meminimalisir berbagai penyimpangan yang dapat terjadi.

PT. Bank Pembangunan Daerah Bali dalam operasionalnya menggunakan sistem informasi yang bernama OLIBs (Online Integrated Banking System). Sistem informasi terintegrasi ini hanya berfokus pada industri perbankan, sehingga setiap produk dan jasa dapat dikembangkan sesuai dengan kemajuan teknologi atau dengan kata lain sistem tersebut memiliki fleksibilitas yang tinggi.

Karyawan di Bank BPD Bali dapat meyakini bahwa ketika menggunakan sistem informasi tersebut akan dapat membantunya dalam meningkatkan kinerjanya dan dapat memberikan kemudahan, sehingga mengurangi upaya pengguna dalam melakukan pekerjaan. Namun, hal-hal yang dapat memengaruhi tingkat kegunaan serta tingkat kemudahan tersebut harus diperhatikan agar dapat menunjang niat pengguna dalam menerapkan sistem.

Adapun identifikasi permasalahan terkait dengan penerapan SIA di Bank BPD Bali, seperti ruang lingkup pekerjaan yang kompleks dan dituntut selesai pada waktu yang terbatas menyebabkan kurang sesuainya penyajian informasi yang diinginkan umumnya oleh perusahaan dan khususnya oleh karyawan. Kemudian perkembangan sistem yang dinamis menyebabkan semakin kompleksnya fitur-fitur dari sistem itu sendiri, sehingga terkadang para karyawan lebih tertarik untuk menggunakan sistem informasi terdahulu ataupun sistem yang dianggap lebih dikuasainya. Adapun permasalahan lainnya seperti pengalaman menerapkan SIA oleh karyawan yang masih kurang menyebabkan terhambatnya kinerja dari kayawan. Dengan demikian, Kantor Pusat PT. Bank Pembangunan Daerah Bali dipilih menjadi lokasi karena dianggap dapat mewakili masalah pokok dalam penelitian ini.

Penelitian ini bertujuan untuk mengetahui pengaruh dari variabel eksternal TAM, dimana variabel tersebut personalisasi (personalization) yang diartikan sebagai tingkat dimana seorang individu menggunakan sistem informasi sesuai dengan keinginan dan kebutuhan perusahaan maupun kebutuhan profesi karyawan, daya tarik alternatif (alternative attractiveness) yaitu tingkat dimana seorang individu memiliki kecenderungan akan alternatif dari sistem informasi yang dipergunakannya dan pengalaman penggunaan sistem yaitu suatu proses atau tingkat penguasaan pengetahuan serta keterampilan seseorang dalam menerapkan sistem terhadap persepsi kegunaan (perceived usefulness) dan persepsi kemudahan penggunaan (perceived ease of use) yang selanjutnya berpengaruh pada niat untuk menggunakan (behavioral intention to use) pada penggunaan sistem informasi akuntansi di Bank BPD Bali.

Penelitian oleh Devi \& Suartana (2014) menunjukkan personalization tidak berpengaruh terhadap persepsi kegunaan dan persepsi kemudahan penggunaan dikarenakan responden berada dalam ruang lingkup yang pekerjaannya kompleks dan dituntut selesai pada waktu yang terbatas. Variabel alternative 
attractiveness (daya tarik alternatif) dalam penelitian Gogus \& Ozer (2014) memiliki pengaruh yang kuat terhadap persepsi kegunaan dan persepsi kemudahan penggunaan, Gogus \& Ozer (2014) menyatakan bahwa variabel alternative attractiveness (daya tarik alternatif) masih baru untuk dipelajari. Sementara variabel pengalaman pengguna sistem tidak memiliki pengaruh terhadap persepsi kegunaan dan persepsi kemudahan penggunaan pada penerapan accounting software di Kantor Accounting Bureaus di Turkey. Gogus \& Ozer (2014) menyatakan persepsi kegunaan memiliki pengaruh terhadap niat untuk tetap menggunakan. Kemudian dari penelitian Yousafzai, Foxall, \& Pallister (2007) persepsi kemudahan penggunaan dinyatakan kurang memiliki pengaruh terhadap niat untuk tetap menggunakan, tetapi semakin mudah suatu sistem seharusnya dapat meningkatkan niat seseorang untuk menggunakan sistem tersebut.

Penelitian ini mengarah pada penelitian yang dilakukan oleh Gogus \& Ozer (2014), namun dalam penelitian ini sampel diambil dari karyawan Kantor Pusat PT. Bank Pembangunan Daerah Bali yang berhubungan dan menggunakan sistem informasi akuntansi dalam menyelesaikan pekerjaannya. Dikarenakan tingkat penerapan sistem informasi akuntansi yang semakin hari semakin kompleks, dipandang perlu penelitian lebih lanjut tentang pengadopsian sistem informasi akuntansi pada lembaga tersebut dengan menggunakan pendekatan TAM.

Pengukuran persepsi kegunaan atau tingkat dimana seseorang yakin bahwa penggunaan sistem akan membantunya dalam meningkatkan kinerja dalam konteks organisasi, salah satunya dipengaruhi oleh personalization. Penelitian Devi \& Suartana (2014) serta Albashrawi \& Motiwalla (2017) menunjukkan bahwa personalization tidak berpengaruh pada persepsi kegunaan. Menurut Devi \& Suartana (2014), personalization merupakan konstruksi yang rumit, dimana ada kemungkinan personalization memiliki efek atau pengaruh yang berbeda dalam konteks yang berbeda.

Silvia (2015) menyatakan bahwa dalam penelitiannya terkait pengaruh personalization terhadap persepsi kegunaan, mendukung adanya suatu pengaruh yang positif dan signifikan antara personalisasi $(\mathrm{P})$ dengan persepsi manfaat (PU). Hasil ini mendukung penelitian oleh Sugiantoro \& Isharijadi (2015) yang membuktikan bahwa personalisasi berpengaruh positif terhadap persepsi manfaat. Personalisasi pada karyawan di Bank BPD Bali ialah berkaitan dengan bagaimana karyawan tersebut menggunakan program OLIBs sesuai dengan keinginan dan kebutuhan profesinya akan suatu informasi tertentu. Dengan demikian, semakin sesuainya sistem informasi yang dibutuhkan maka akan memengaruhi kegunaan penggunaan sistem tersebut untuk peningkatan kinerja dari karyawan di Bank BPD. Dari penjelasan tersebut, memunculkan hipotesis sebagai berikut,

$\mathrm{H}_{1}$ : Personalisasi berpengaruh positif pada persepsi kegunaan.

Daya tarik alternatif dapat menjadi pengukuran berikutnya dari persepsi kegunaan. Gogus \& Ozer (2014) menemukan bahwa daya tarik alternatif memiliki pengaruh yang kuat terhadap persepsi kegunaan. Pada penelitian Ping (1993), Sharma \& Patterson (2000) serta Zhang et al., (2009) dalam Gogus \& Ozer (2014) daya tarik alternatif ditemukan positif berkaitan dengan perilaku 
oportunistik dan berbeda dari hubungan lainnya, dikarenakan pelanggan akan didorong untuk mencoba kebaikan alternatif yang ada. Daya tarik alternatif berkaitan dengan kecenderungan karyawan pada sistem informasi yang digunakan di Bank BPD Bali untuk menyelesaikan pekerjaannya. Jika karyawan telah menguasai program OLIBs dengan baik, maka tidak diperlukan lagi jenis sistem informasi yang lainnya, dapat diduga sistem tersebut telah memberikan manfaat yang lebih bagi pengguna, kemudian nantinya dapat meningkatkan kinerjanya. Dari penjelasan tersebut, memunculkan hipotesis sebagai berikut,

$\mathrm{H}_{2}$ : Daya tarik alternatif berpengaruh positif pada persepsi kegunaan.

Persepsi kegunaan juga dapat diukur dengan pengalaman. Dalam penelitian Yuda (2014) dan Abdullah \& Ward (2016) menyatakan bahwa pengalaman berpengaruh signifikan positif terhadap persepsi kegunaan. Hasil penelitian tersebut menunjukan bahwa semakin tinggi pengalaman seseorang kepada sistem informasi maka semakin tinggi tingkat kegunaan yang dirasakan orang tersebut ketika menggunakan sistem informasi. Hasil penelitian tersebut sesuai dengan hasil penelitian yang diperoleh Zhou (2012) yang membuktikan efek positif dari flow experience adopsi pengguna mobile banking. Namun dalam penelitian Gogus \& Ozer (2014), pengalaman tidak memiliki pengaruh terhadap persepsi kegunaan, hal tersebut dikarenakan mungkin karena jangka panjang pengalaman mengurangi kepentingan keseluruhan yang diberikan dalam penggunaan sistem. Pengalaman karyawan di Bank BPD Bali dapat menjadikan karyawan memiliki pengetahuan yang lebih dalam sistem informasi, dengan demikian maka karyawan tersebut akan mendapatkan manfaat dalam menyelesaikan pekerjaannya dengan cepat jika telah memiliki pengalaman karena dianggap sudah ahli. Dari penjelasan tersebut, memunculkan hipotesis sebagai berikut,

$\mathrm{H}_{3}$ : Pengalaman pengguna sistem berpengaruh positif pada persepsi kegunaan.

Sama seperti persepsi kegunaan, persepsi kemudahan penggunaan juga diukur oleh personalization. Penelitian Devi \& Suartana (2014) serta Albashrawi \& Motiwalla (2017) menunjukkan bahwa personalization tidak berpengaruh pada persepsi kemudahan penggunaan. Devi \& Suartana (2014) menyebutkan personalization lebih terkait kepada ketersediaan fitur-fitur dalam rangka memuaskan kebutuhan melaksanakan tugas, bukan untuk memudahkan penggunaan sistem, karena itulah pada penelitian Chau \& Lai (2003) tidak disusun hipotesis yang menghubungkan personalization dengan persepsi kemudahan penggunaan. Namun dalam penelitian Silvia (2015) tingkat personalisasi memiliki pengaruh yang positif terhadap kemudahan penggunaan. Hasil tersebut juga didukung oleh Sugiantoro \& Isharijadi (2015) yang membuktikan bahwa personalisasi berpengaruh positif terhadap persepsi kemudahan dalam pengguna Internet Banking Di PT. Bank BRI (Persero), Tbk. Cabang Madiun. Ketika karyawan di Bank BPD Bali menggunakan program OLIBs, tentunya diharapkan agar sesuai dengan keinginan dan kebutuhannya akan suatu informasi tersebut. Keterkaitannya dengan kemudahan penggunaan, jika penyajian informasinya telah sesuai dengan yang diperlukan, maka akan mempengaruhi kemudahannya dalam menggunakan suatu sistem informasi. Dari penjelasan tersebut, memunculkan hipotesis sebagai berikut,

$\mathrm{H}_{4}$ : Personalisasi berpengaruh positif pada persepsi kemudahan penggunaan. 
Zhang et al., (2009) menemukan bahwa niat blogger untuk beralih layanan blog mereka sangat terkait dengan daya tarik alternatif. Etzel et al., (1997) menyatakan proses pembelian membawa risiko pembelian yang berbeda seperti keuangan, kinerja, risiko psikologis maka dari itu peluang alternatif yang baik mungkin mempersingkat proses pengambilan keputusan sehingga mengurangi risiko tersebut. Akibatnya, semakin banyak peluang alternatif, pengguna sistem akan lebih percaya diri serta akan menjadi akuntan yang berhasil dalam menerapkan sistem, kemudian dapat memudahkan penggunaan perangkat lunak di tempat kerja. Sebagian besar, pengguna menyadari kompleksitas menggunakan SIA yang membutuhkan keterampilan teknis yang baik, dengan demikian daya tarik alternatif yang tinggi akan meningkatkan pendekatan yang nantinya akan memberikan kemudahan untuk digunakan. Penelitian Gogus \& Ozer (2014) menemukan daya tarik alternatif memiliki pengaruh yang kuat terhadap kemudahan penggunaan. Daya tarik alternatif pada karyawan di Bank BPD Bali dalam menggunakan sistem informasi untuk menyelesaikan pekerjaannya akan berkaitan dengan berbagai jenis pilihan sistem informasi, jika dirasa sistem informasinya telah mudah digunakan maka tidak akan menimbulkan ketertarikan dengan sistem informasi yang lainnya, sehingga tidak akan terjadi hambatan dalam penerapan sistem tersebut. Dari penjelasan tersebut, memunculkan hipotesis sebagai berikut,

$\mathrm{H}_{5}$ : Daya tarik alternatif berpengaruh positif pada persepsi kemudahan penggunaan.

Sama halnya seperti persepsi kegunaan, persepsi kemudahan penggunaan juga dapat diukur dengan pengalaman. Penelitian Yuda (2014) dan Abdullah \& Ward (2016) menyatakan bahwa pengalaman berpengaruh signifikan positif terhadap hubungan antara kemudahan penggunaan dengan minat perilaku menggunakan SIMGAJI. Semakin banyak pengalaman seseorang dalam menggunakan sistem informasi maka semakin tinggi pula tingkat kemudahan yang dirasakan orang tersebut ketika menggunakan sistem informasi. Namun hasil penelitian Gogus \& Ozer (2014) serta Alharbi \& Drew (2014) menyatakan pengalaman tidak memiliki pengaruh yang kuat untuk kemudahan penggunaan. Pengalaman yang baik dalam penerapan sistem oleh karyawan di Bank BPD Bali dapat menjadikan pengguna lebih percaya diri dalam menyelesaikan pekerjaannya. Dengan banyaknya pengalaman karyawan tersebut akan dapat memudahkannya dan meminimalisir hambatan dalam menggunakan software serta dapat dipastikan secara dua kali lipat pemahaman user tersebut akan semakin baik. Dari penjelasan tersebut, memunculkan hipotesis sebagai berikut,

$\mathrm{H}_{6}$ : Pengalaman pengguna sistem berpengaruh positif pada persepsi kemudahan penggunaan.

Penelitian Aditya \& Wardhana (2016) menyatakan variabel persepsi kegunaan berpengaruh secara signifikan terhadap niat untuk tetap menggunakan pada pengguna instant messaging LINE di Indonesia. Hasil penelitian ini sejalan dengan penelitian Gogus \& Ozer (2014), Nelwan (2014), Prasada Bangkara \& Mimba (2016), Lee \& Wella (2019), Faradila \& Soesanto (2016), Afifah \& Widyanesti (2017), Fathali \& Okada (2018) serta Apriyani \& Suharti (2017) yang menyatakan bahwa persepsi kegunaan berpengaruh signifikan terhadap niat untuk menggunakan (niat untuk tetap menggunakan). 
Namun pada penelitian Ardhiani (2015) dan Septiani, et al., (2017) menyatakan bahwa manfaat yang dirasakan (persepsi kegunaan) tidak memengaruhi niat perilaku pengguna.

Ketika karyawan Bank BPD Bali merasakan banyak manfaat yang didapatkan dari penggunaan program OLIBs, maka hal tersebut akan dapat memengaruhi niatnya untuk menggunakan sistem tersebut secara berlanjut. Dari penjelasan tersebut, memunculkan hipotesis sebagai berikut,

$\mathrm{H}_{7}$ : Persepsi kegunaan berpengaruh positif pada niat untuk tetap menggunakan.

Penelitian Aditya \& Wardhana (2016) menyatakan persepsi kemudahan penggunaan berpengaruh secara signifikan terhadap behavioral intention pada pengguna instant messaging LINE di Indonesia. Hasil penelitian ini konsisten dengan hasil penelitian Nelwan (2014), Prasada Bangkara \& Mimba (2016), Wibowo, Rosmauli, \& Suhud (2015), Faradila \& Soesanto (2016), Afifah \& Widyanesti (2017), Fathali \& Okada (2018) serta Apriyani \& Suharti (2017) yang menyatakan bahwa persepsi kemudahan penggunaan berpengaruh signifikan terhadap niat untuk tetap menggunakan. Namun Holden \& Karsh (2010), Ahmad \& Pambudi (2013) dan Rakhmawati \& Isharijadi (2013) menemukan persepsi kemudahan penggunaan tidak memiliki pengaruh dengan niat untuk tetap menggunakan. Ketika karyawan Bank BPD Bali merasakan kemudahan yang didapatkan dari penggunaan program OLIBs, maka hal tersebut akan dapat memengaruhi niatnya untuk menggunakan sistem tersebut secara berlanjut. Dari penjelasan tersebut, memunculkan hipotesis sebagai berikut,

$\mathrm{H}_{8}$ : Persepsi kegunaan berpengaruh positif pada niat untuk tetap menggunakan.

\section{METODE PENELITIAN}

Penelitian ini dilakukan di Kantor Pusat PT. Bank Pembangunan Daerah Bali, Provinsi Bali. Lokasi tersebut dipilih dengan alasan karena Peran Bank BPD sangat penting untuk menunjang pertumbuhan perekonomian daerah, khususnya UMKM yang lumrah terdapat di Bali, maka sistem informasi akuntansi penting untuk diterapkan secara optimal agar peningkatan kinerja Bank BPD meningkat. Adapun alasan lain yaitu keterjangkauan lokasi penelitian baik dari segi tenaga, dana maupun efisiensi waktu. Berdasarkan pertimbangan tersebut, lokasi yang dipilih diperkirakan dapat mewakili masalah pokok dalam penelitian ini. Populasi dalam penelitian ini adalah seluruh karyawan Divisi Teknologi dan Akuntansi di Kantor Pusat PT. Bank BPD Bali. Dalam penelitian ini yang menjadi sampel penelitian adalah 51 orang, dimana 51 sampel tersebut adalah karyawan PT. Bank BPD Bali yang terlibat dalam penggunaan SIA baik mengelola maupun menerapkannya dalam melakukan pekerjaan, kemudian hal tersebut karena sesuai dengan teknik pengambilan sampling yang dipilih dalam penelitian ini, yaitu teknik Non Probability Sampling.

Analisis regresi linier berganda (multiple linear regression) digunakan untuk menguji hipotesis yang ada yaitu untuk melihat pengaruh personalisasi, daya tarik alternatif dan pengalaman pengguna sistem pada persepsi kegunaan serta persepsi kemudahan penggunaan. Analisis linier berganda digunakan untuk memecahkan rumusan masalah yang ada, yaitu untuk melihat pengaruh 
dua variabel atau lebih. Model persamaan analisis regresi linier berganda ditunjukkan oleh persamaan regresi berikut Sugiyono (2017)

$$
\begin{aligned}
& X_{4}=\alpha+\beta_{1} X_{1}+\beta_{2} X_{2}+\beta_{3} X_{3}+\varepsilon \\
& X_{5}=\alpha+\beta_{1} X_{1}+\beta_{2} X_{2}+\beta_{3} X_{3}+\varepsilon \\
& Y=\alpha+\beta_{4} X_{4}+\beta_{5} X_{5}+\varepsilon \ldots \ldots \ldots
\end{aligned}
$$

Keterangan:

$\mathrm{Y} \quad=$ Niat untuk tetap menggunakan

$\mathrm{X}_{4} \quad=$ Persepsi kegunaan

$\mathrm{X}_{5} \quad=$ Persepsi kemudahan penggunaan

a $\quad=$ Konstanta

$\beta_{1} \beta_{2} \beta_{3} \beta_{4} \beta_{5}=$ Koefisien regresi untuk masing-masing variabel independen

$\mathrm{X}_{1} \quad=$ Personalisasi

$\mathrm{X}_{2} \quad$ = Daya Tarik Alternatif

$\mathrm{X}_{3} \quad=$ Pengalaman Pengguna Sistem

$\varepsilon \quad=$ Error

\section{HASIL DAN PEMBAHASAN}

Analisis statistik deskriptif dipergunakan untuk menggambarkan atau menjelaskan suatu data pada variabel penelitian berdasarkan jumlah sampel,

\begin{tabular}{|c|c|c|c|c|c|}
\hline Variabel & $\mathrm{N}$ & Min. & Max. & Mean & $\begin{array}{l}\text { Std. } \\
\text { Deviasi }\end{array}$ \\
\hline Personalisasi & 51 & 1,75 & 4,00 & 2,9216 & 0,60928 \\
\hline Daya Tarik Alternatif & 51 & 2,00 & 4,00 & 3,1078 & 0,62701 \\
\hline $\begin{array}{l}\text { Pengalaman } \\
\text { Sistem }\end{array}$ & 51 & 2,33 & 4,00 & 3,1176 & 0,56104 \\
\hline Peceived Usefulness & 51 & 2,00 & 4,00 & 3,0863 & 0,63656 \\
\hline $\begin{array}{ll}\text { Persepsi kemudahan } \\
\text { penggunaan }\end{array}$ & 51 & 2,00 & 4,00 & 3,1340 & 0,59350 \\
\hline $\begin{array}{l}\text { Niat untuk tetap } \\
\text { menggunakan }\end{array}$ & 51 & 2,00 & 4,00 & 3,1078 & 0,62701 \\
\hline
\end{tabular}
nilai rata - rata (mean), standar deviasi, nilai maksimum, dan nilai minimum.

Tabel 1. Hasil Uji Statistik Deskriptif

Sumber: Data Penelitian, 2019

Personalisasi $\left(\mathrm{X}_{1}\right)$ memiliki nilai minimum variabel sebesar 1,75 dan nilai maksimum sebesar 4,00. Nilai rata-rata variabel personalisasi sebesar 2,92 hal ini berarti rata-rata personalisasi pada sampel amatan dalam penelitian ini bernilai 2,92. Deviasi standar variabel personalisasi adalah 0,60928 yang memiliki makna dimana terjadi penyimpangan nilai personalisasi pada nilai rata-ratanya sebesar 0,60928 . Daya Tarik Alternatif $\left(X_{2}\right)$ memiliki nilai minimum variabel sebesar 2,00 dan nilai maksimum sebesar 4,00. Nilai rata-rata variabel daya tarik alternatif sebesar 3,10 hal ini berarti rata-rata daya tarik alternatif pada sampel amatan dalam penelitian ini bernilai 3,10. Deviasi standar variabel daya tarik alternatif adalah 0,62701 yang memiliki makna dimana terjadi penyimpangan nilai daya tarik alternatif pada nilai rata-ratanya sebesar 0,62701. Pengalaman Pengguna Sistem $\left(X_{3}\right)$ memiliki nilai minimum variabel sebesar 2,33 dan nilai maksimum sebesar 4,00. Nilai rata-rata variabel pengalaman pengguna sistem sebesar 3,11 hal ini berarti rata-rata pengalaman pengguna sistem pada sampel amatan dalam penelitian ini bernilai 3,11. Deviasi standar variabel pengalaman pengguna 
sistem adalah 0,56104 yang memiliki makna dimana terjadi penyimpangan nilai pengalaman pengguna sistem pada nilai rata-ratanya sebesar 0,56104. Persepsi Kegunaan $\left(X_{4}\right)$ memiliki nilai minimum variabel sebesar 2,00dan nilai maksimum sebesar 4,00. Nilai rata-rata variabel persepsi kegunaan sebesar 3,08 hal ini berarti rata-rata persepsi kegunaan pada sampel amatan dalam penelitian ini bernilai 3,08. Deviasi standar variabel persepsi kegunaan adalah 0,63656 yang memiliki makna dimana terjadi penyimpangan nilai persepsi kegunaan pada nilai rata-ratanya sebesar 0,63656. Persepsi Kemudahan Penggunaan $\left(X_{5}\right)$ memiliki nilai minimum variabel sebesar 2,00 dan nilai maksimum sebesar 4,00. Nilai rata-rata variabel persepsi kemudahan penggunaan sebesar 3,08 hal ini berarti rata-rata persepsi kemudahan penggunaan pada sampel amatan dalam penelitian ini bernilai 3,08. Deviasi standar variabel persepsi kemudahan penggunaanadalah 0,59350 yang memiliki makna dimana terjadi penyimpangan nilai persepsi kemudahan penggunaanpada nilai rata-ratanya sebesar 0,59350. Niat untuk tetap Menggunakan (Y) memiliki nilai minimum variabel sebesar 2,00 dan nilai maksimum sebesar 4,00. Nilai rata-rata variabel niat untuk tetap menggunakan sebesar 3,10 hal ini berarti rata-rata niat untuk tetap menggunakan pada sampel amatan dalam penelitian ini bernilai 3,10. Deviasi standar variabel niat untuk tetap menggunakan adalah 0,62701 yang memiliki makna dimana terjadi penyimpangan nilai niat untuk tetap menggunakan pada nilai rata-ratanya sebesar 0,62701 .

Tabel 2. Hasil Uji Regresi Linier Berganda

\begin{tabular}{|c|c|c|c|c|c|c|c|}
\hline \multirow{2}{*}{\multicolumn{2}{|c|}{ Model }} & \multicolumn{2}{|c|}{$\begin{array}{l}\text { Unstandardized } \\
\text { Coefficients }\end{array}$} & \multirow{2}{*}{$\begin{array}{l}\text { Standardized } \\
\text { Coefficients }\end{array}$} & \multirow[b]{2}{*}{$\mathrm{t}$} & \multirow[b]{2}{*}{ Sig. } & \multirow[b]{2}{*}{ Hasil } \\
\hline & & $\mathrm{B}$ & Std. Error & & & & \\
\hline \multirow[t]{10}{*}{1} & (Constant) & 6,326 & 3,259 & & 1,941 & 058 & \\
\hline & Personalisasi & ,467 & 163 & ,357 & 2,864 & ,006 & Diterima \\
\hline & Daya Tarik Alternatif & 626 & 150 & ,494 & 4,188 & ,000 & Diterima \\
\hline & Pengalaman & -442 & 237 &,- 234 & $-1,861$ & 069 & Ditolak \\
\hline & Pengguna Sistem & & & & & & \\
\hline & Adjusted R Square & ,324 & & & & & \\
\hline & $\mathrm{F}$ & 8,993 & & & & & \\
\hline & Sig. & ,000 & & & & & \\
\hline & (Constant) & 2,317 & 737 & & 3,145 & ,003 & \\
\hline & Personalisasi & ,947 & 909 & 151 & 1,041 & ,303 & Ditolak \\
\hline \multirow[t]{7}{*}{2} & Daya Tarik Alternatif & 2,192 & 866 & ,343 & 2,530 & ,015 & Diterima \\
\hline & Pengalaman & $-1,383$ & 1,089 & -185 & $-1,271$ & 210 & Ditolak \\
\hline & Pengguna Sistem & & & & & & \\
\hline & Adjusted R Square & 107 & & & & & \\
\hline & $\mathrm{F}$ & 2,991 & & & & & \\
\hline & Sig. & ,040 & & & & & \\
\hline & (Constant) & 3,759 & 1,419 & & 2,648 & 011 & \\
\hline \multirow{6}{*}{3} & Persepsi Kegunaan & 631 & 078 & 801 & 8,113 & 000 & Diterima \\
\hline & Persepsi Kemudahan & 057 & 070 & 080 &,- 815 & 419 & Ditolak \\
\hline & Penggunaan & & & & & & \\
\hline & Adjusted R Square & ,582 & & & & & \\
\hline & $\mathrm{F}$ & 35,873 & & & & & \\
\hline & Sig. & ,000 & & & & & \\
\hline
\end{tabular}


Berdasarkan Tabel 2 dapat disusun persamaan regresi sebagai berikut :

$$
\begin{aligned}
& X_{4}=\alpha+\beta_{1} X_{1}+\beta_{2} X_{2}+\beta_{3} X_{3}+\varepsilon \\
& X_{4}=6,326+0,467 X_{1}+0,626 X_{2}+-0,442 X_{3}+\varepsilon \\
& X_{5}=\alpha+\beta_{1} X_{1}+\beta_{2} X_{2}+\beta_{3} X_{3}+\varepsilon \\
& X_{5}=2,317+0,947 X_{1}+2,192 X_{2}+-1,383 X_{3}+\varepsilon \\
& Y=\alpha+\beta_{4} X_{4}+\beta_{5} X_{5}+\varepsilon \\
& Y=3,759+0,631 X_{4}+0,057 X_{5}+\varepsilon
\end{aligned}
$$

Nilai konstanta (a) sebesar 6,326 memiliki arti jika variabel personalisasi, daya tarik alternatif dan pengalaman pengguna sistem dinyatakan konstan pada angka 0, maka nilai persepsi kegunaan sebesar 6,326. Koefisien regresi $\beta 1$ untuk variabel personalisasi sebesar 0,467. Koefisien regresi yang bernilai positif memiliki arti jika personalisasi meningkat sebesar satu satuan, maka persepsi kegunaan akan meningkat sebesar 0,467 satuan dengan asumsi variabel bebas lainnya konstan. Koefisien regresi $\beta 2$ untuk variabel daya tarik alternatif sebesar 0,626. Koefisien regresi yang bernilai positif memiliki arti jika daya tarik alternatif meningkat sebesar satu satuan, maka persepsi kegunaan akan meningkat sebesar 0,626 satuan dengan asumsi variabel bebas lainnya konstan. Koefisien regresi $\beta 3$ untuk variabel pengalaman pengguna sistem sebesar -0,442. Koefisien regresi yang bernilai negatif memiliki arti jika pengalaman pengguna sistem meningkat sebesar satu satuan, maka persepsi kegunaan akan berkurang sebesar -0,442 satuan dengan asumsi variabel bebas lainnya konstan.

Nilai konstanta (a) sebesar 2,317 memiliki arti jika variabel personalisasi, daya tarik alternatif dan pengalaman pengguna sistem dinyatakan konstan pada angka 0, maka nilai persepsi kemudahan penggunaan sebesar 2,317. Koefisien regresi $\beta 1$ untuk variabel personalisasi sebesar 0,947 . Koefisien regresi yang bernilai positif memiliki arti jika personalisasi meningkat sebesar satu satuan, maka persepsi kemudahan penggunaan akan meningkat sebesar 0,947 satuan dengan asumsi variabel bebas lainnya konstan. Koefisien regresi $\beta 2$ untuk variabel daya tarik alternatif sebesar 2,192. Koefisien regresi yang bernilai positif memiliki arti jika daya tarik alternatif meningkat sebesar satu satuan, maka persepsi kemudahan penggunaan akan meningkat sebesar 2,192 satuan dengan asumsi variabel bebas lainnya konstan. Koefisien regresi $\beta 3$ untuk variabel pengalaman pengguna sistem sebesar -1,383. Koefisien regresi yang bernilai negatif memiliki arti jika pengalaman pengguna sistem meningkat sebesar satu satuan, maka persepsi kemudahan penggunaan akan berkurang sebesar -1,383 satuan dengan asumsi variabel bebas lainnya konstan.

Nilai konstanta (a) sebesar 3,759 memiliki arti jika variabel persepsi kegunaan dan persepsi kemudahan penggunaan dinyatakan konstan pada angka 0 , maka nilai niat untuk tetap menggunakan sebesar 3,759. Koefisien regresi $\beta 4$ untuk variabel persepsi kegunaan sebesar 0,631. Koefisien regresi yang bernilai positif memiliki arti jika persepsi kegunaan meningkat sebesar satu satuan, maka niat untuk tetap menggunakan akan meningkat sebesar 0,631 satuan dengan asumsi variabel bebas lainnya konstan. Koefisien regresi $\beta 5$ untuk variabel persepsi kemudahan penggunaan sebesar 0,057. Koefisien regresi yang bernilai positif memiliki arti jika persepsi kemudahan penggunaan meningkat sebesar satu satuan, maka niat untuk tetap menggunakan akan meningkat sebesar 0,057 satuan dengan asumsi variabel bebas lainnya konstan. 
Koefisien determinasi yang digunakan pada analisis regresi linier berganda adalah nilai Adjusted $\mathrm{R}^{2}$. Hasil analisis menunjukkan bahwa nilai Adjusted $\mathrm{R}^{2}$ pada persamaan pertama adalah sebesar 0,324 . Ini berarti perubahan yang terjadi pada persepsi kegunaan dapat dijelaskan oleh personalisasi, daya tarik alternatif dan pengalaman pengguna sistem sebesar 32,4 persen sedangkan sisanya dijelaskan oleh faktor lain yang tidak diuji dalam penelitian ini. Kemudian pada persamaan kedua nilai Adjusted $\mathrm{R}^{2}$ adalah sebesar 0,107. Ini berarti perubahan yang terjadi pada persepsi kemudahan penggunaan dapat dijelaskan oleh personalisasi, daya tarik alternatif dan pengalaman pengguna sistem sebesar 10,7 persen sedangkan sisanya dijelaskan oleh faktor lain. Pada persamaan ketiga nilai Adjusted $\mathrm{R}^{2}$ adalah sebesar 0,582 . Ini berarti perubahan yang terjadi pada niat untuk tetap menggunakan dapat dijelaskan oleh persepsi kegunaan dan persepsi kemudahan penggunaan sebesar 58,2 persen sedangkan sisanya dijelaskan oleh faktor lain yang tidak terdapat dalam model penelitian.

Tabel 2 menunjukkan bahwa nilai $\mathrm{F}_{\text {hitung }}$ yang diperoleh pada persamaan pertama adalah 8,993 dengan signifikansi 0,000. Kemudian pada persamaan kedua adalah 2,991 dengan signifikansi 0,040 dan pada persamaan ketiga adalah 35,873 dengan signifikansi 0,000. Signifikansi tersebut jelas lebih kecil dari Alpha $(\alpha=0,05)$ maka model regresi telah memenuhi prasyarat kelayakan model regresi.

Hipotesis pertama menyatakan bahwa personalisasi berpengaruh positif pada persepsi kegunaan. Pada Tabel 2 dapat dilihat bahwa nilai signifikansi uji $t$ untuk variabel personalisasi sebesar 0,006 yaitu lebih kecil dari 0,05 dengan koefisien regresi bernilai positif yaitu sebesar 0,467. Berdasarkan hal tersebut maka hipotesis pertama $\mathrm{H}_{1}$ diterima. Artinya secara parsial personalisasi berpengaruh positif pada persepsi kegunaan.

Hipotesis kedua menyatakan bahwa daya tarik alternatif berpengaruh positif pada persepsi kegunaan. Pada Tabel 2 dapat dilihat bahwa nilai signifikansi uji t untuk variabel daya tarik alternatif sebesar 0,000 yaitu lebih kecil dari 0,05 dengan koefisien regresi bernilai positif yaitu sebesar 0,626. Berdasarkan hal tersebut maka hipotesis kedua $\mathrm{H}_{2}$ diterima. Artinya secara parsial daya tarik alternatif berpengaruh positif pada persepsi kegunaan.

Hipotesis ketiga menyatakan bahwa pengalaman pengguna sistem berpengaruh negatif pada persepsi kegunaan. Pada Tabel 2 dapat dilihat bahwa nilai signifikansi uji t untuk variabel daya tarik alternatif sebesar 0,069 yaitu lebih besar dari 0,05 dengan koefisien regresi bernilai negatif yaitu sebesar -0,442. Berdasarkan hal tersebut maka hipotesis ketiga $\mathrm{H}_{3}$ ditolak. Artinya secara parsial pengalaman pengguna sistem tidak berpengaruh pada persepsi kegunaan.

Hipotesis keempat menyatakan bahwa personalisasi berpengaruh negatif pada persepsi kemudahan penggunaan. Pada Tabel 2 dapat dilihat bahwa nilai signifikansi uji $t$ untuk variabel personalisasi sebesar 0,303 yaitu lebih besar dari 0,05 dengan koefisien regresi bernilai positif yaitu sebesar 0,947. Berdasarkan hal tersebut maka hipotesis keempat $\mathrm{H}_{4}$ ditolak. Artinya secara parsial personalisasi tidak berpengaruh pada persepsi kemudahan penggunaan.

Hipotesis kelima menyatakan bahwa daya tarik alternatif berpengaruh positif pada persepsi kemudahan penggunaan. Pada Tabel 2 dapat dilihat bahwa nilai signifikansi uji t untuk variabel daya tarik alternatif sebesar 0,015 yaitu lebih 
kecil dari 0,05 dengan koefisien regresi bernilai positif yaitu sebesar 2,192. Berdasarkan hal tersebut maka hipotesis kelimaH ${ }_{5}$ diterima. Artinya secara parsial daya tarik alternatif berpengaruh positif pada persepsi kemudahan penggunaan.

Hipotesis keenam menyatakan bahwa pengalaman pengguna sistem berpengaruh negatif pada persepsi kemudahan penggunaan. Pada Tabel 2 dapat dilihat bahwa nilai signifikansi uji $\mathrm{t}$ untuk variabel pengalaman pengguna sistem sebesar 0,210 yaitu lebih besar dari 0,05 dengan koefisien regresi bernilai negatif yaitu sebesar -1,383. Berdasarkan hal tersebut maka hipotesis keempat $\mathrm{H}_{6}$ ditolak. Artinya secara parsial pengalaman pengguna sistem tidak berpengaruh pada persepsi kemudahan penggunaan.

Hipotesis ketujuh menyatakan bahwa persepsi kegunaan berpengaruh positif pada niat untuk tetap menggunakan. Pada Tabel 2 dapat dilihat bahwa nilai signifikansi uji t untuk variabel persepsi kegunaan sebesar 0,000 yaitu lebih kecil dari 0,05 dengan koefisien regresi bernilai positif yaitu sebesar 0,631. Berdasarkan hal tersebut maka hipotesis kelima $\mathrm{H}_{7}$ diterima. Artinya secara parsial persepsi kegunaan berpengaruh positif pada niat untuk tetap menggunakan.

Hipotesis kedelapan menyatakan bahwa persepsi kemudahan penggunaan berpengaruh negatif pada niat untuk tetap menggunakan. Pada Tabel 2 dapat dilihat bahwa nilai signifikansi uji $\mathrm{t}$ untuk variabel persepsi kemudahan penggunaan sebesar 0,419 yaitu lebih besar dari 0,05 dengan koefisien regresi bernilai positif yaitu sebesar 0,57 . Berdasarkan hal tersebut maka hipotesis kelima $\mathrm{H}_{8}$ ditolak. Artinya secara parsial persepsi kemudahan penggunaan tidak berpengaruh pada niat untuk tetap menggunakan.

\section{SIMPULAN}

Personalisasi berpengaruh positif terhadap persepsi kegunaan, hal ini berarti pengguna SIA di Kantor Pusat PT. Bank Pembangunan Daerah Bali dapat memanfaatkan penerapan SIA (program OLIBs) dengan baik. Selanjutnya dengan menerapkan sistem tersebut, maka isi informasinya relevan dengan kebutuhan sehingga dapat memberikan manfaat yang lebih dalam penerapannya. Personalisasi tidak berpengaruh terhadap persepsi kemudahan penggunaan yang artinya ruang lingkup pekerjaan karyawan sangat kompleks dan dituntut selesai pada waktu yang terbatas menyebabkan kemudahan penggunaan sistem tersebut tidak dapat dinilai. Daya tarik alternatif berpengaruh positif terhadap persepsi kegunaan dan persepsi kemudahan penggunaan, hal ini berarti daya tarik alternatif karyawan terhadap sistem yang dipergunakannya dapat memengaruhi manfaat serta kemudahan dari sistem itu sendiri. Pengalaman pengguna sistem tidak berpengaruh terhadap persepsi kegunaan dan persepsi kemudahan penggunaan, yang artinya semakin lama seseorang menggunakan SIA dalam hal ini program OLIBs, semakin besar kemungkinan penggunaan sistem tersebut menjadi keniscayaan. Persepsi kegunaan berpengaruh positif terhadap niat untuk tetap menggunakan yang artinya manfaat dari penggunaan sistem tersebut salah satunya yaitu dapat meningkatkan efisiensi waktu dalam bekerja sehingga karyawan akan mempergunakan sistem tersebut secara berkelanjutan agar dapat mendorong 
niat untuk menerapkan. Penelitian menemukan bahwa persepsi kemudahan penggunaan tidak berpengaruh terhadap niat untuk tetap menggunakan yang artinya SIA dalam hal ini program OLIBs bersifat mandatory atau wajib untuk digunakan. Kemudian disaat sekarang karyawan khususnya karyawan pengguna sistem tersebut sudah tidak lagi mempermasalahkan kemudahan penggunaan karena karyawan sudah menguasai teknologi.

\section{REFERENSI}

Abdullah, F., \& Ward, R. (2016). Developing a General Extended Technology Acceptance Model for E-Learning (GETAMEL) by analysing commonly used external factors. Computers in Human Behavior. https:// doi.org/10.1016/j.chb.2015.11.036

Aditya, R., \& Wardhana, A. (2016). Pengaruh perceived usefulness dan perceived ease of use terhadap behavioral intention dengan pendekatan Technology Acceptance Model (TAM) pada pengguna Instant Messaging LINE di Indonesia. Jurnal Siasat Bisnis. https:// doi.org/10.20885/jsb.vol20.iss1.art3

Afifah, F., \& Widyanesti, S. (2017). Analisis penggunaan mobile banking dengan mengadopsi technology acceptance model (tam) (studi kasus pada bank central asia di jakarta). E-Proceeding of Management.

Ahmad, \& Pambudi, B. S. (2013). Pengaruh Persepsi Manfaat, Persepsi Kemudahan, Keamanan Dan Ketersediaan Fitur Terhadapminat Ulang Nasabah Bank Dalam Menggunakan Internet Banking (Studi Pada Program Layanan Internet Banking Bri). Journal of Chemical Information and Modeling, 53(9), 1689-1699.

https://doi.org/10.1017/CBO9781107415324.004

Albashrawi, M., \& Motiwalla, L. (2017). Privacy and Personalization in Continued Usage Intention of Mobile Banking: An Integrative Perspective. Information Systems Frontiers. https:/ / doi.org/10.1007/ s10796-017-9814-7

Alharbi, S., \& Drew, S. (2014). Using the Technology Acceptance Model in Understanding Academics' Behavioural Intention to Use Learning Management Systems. International Journal of Advanced Computer Science and Applications. https://doi.org/10.14569/ijacsa.2014.050120

Apriyani, N., \& Suharti. (2017). Analisis Pengaruh Persepsi Kebermanfaatan, Persepsi Kemudahan dan Kepercayaan terhadap Minat Beli Ulang Pengguna Smartphone Xiaomi. Jurnal Manajemen Dewantara.

Ardhiani, L. N. (2015). Analisis Faktor-Faktor Penerimaan Penggunaan Quipperschool.Com Dengan Menggunakan Pendekatan Technology Acceptance Model (Tam) Dan Theory of Planned Behavior (Tpb) Di Sma Negeri 7 Yogyakarta. Skripsi. https:// doi.org/10.1017/CBO9781107415324.004

Chau, P. Y. K., \& Lai, V. S. K. (2003). An empirical investigation of the determinants of user acceptance of Internet banking. Journal of Organizational Computing and Electronic Commerce. https://doi.org/10.1207/S15327744JOCE1302_3

Davis, F.D. (1989). Perceived Usefulness, Perceived Ease of Use, and Acceptance of Information System Technology. Management Information Systems Quarterly, 13(3), pp: 319-339. 
Davis, Fred D. (1986). Technology Acceptance Model for Empirically Testing New End-User Information System Theory and Results. Dissertation. Massachusetts Institute of Technology (MIT).

Devi, S. (2014). Analisis technology acceptance model (tam) terhadap penggunaan sistem informasi di nusa indah beach hotel \& spa fakultas ekonomi dan bisnis universitas udayana ( unud ), bali, indonesia fakultas ekonomi. E-Jurnal Akuntansi Universitas Udayana, 1, 167-184.

Doll, W. J., Hendrickson, A., \& Deng, X. (1998). Using Davis's perceived usefulness and ease-of-use instruments for decision making: A confirmatory and multigroup invariance analysis. Decision Sciences, 29(4), 839-869. https:// doi.org/10.1111/j.1540-5915.1998.tb00879.x

Etzel, M.J, W.J Stanton \& B.Walker. ( 1997). Marketing, McGraw-Hill, New-york N.Y-tekrar bak

Faradila, R. S. N., \& Soesanto, H. (2016). Analisis Pengaruh Persepsi Kemudahan Penggunaan dan Persepsi Manfaat terhadap Minat Beli dengan Kepercayaan Sebagai Variabel Intervening (Studi pada Pengunjung Toko Online berrybenka.com di Kalangan Mahasiswa Universitas Diponegoro). Jurnal Studi Manajemen Organisasi. https:// doi.org/10.14710/jsmo.v13i2.13406

Fathali, S., \& Okada, T. (2018). Technology acceptance model in technologyenhanced OCLL contexts: A self-determination theory approach. Australasian Journal of Educational Technology. https:/ / doi.org/10.14742/ajet.3629

Gogus, C. G., \& Ozer, G. (2014). The roles of technology acceptance model antecedents and switching cost on. Academy of Management Sciences Journal.

Hartono Musakini, J. (2014). Analisis \& Desain Sistem Informasi Sitem Informasi: Pendekatan terstruktur teori dan praktik aplikasi bisnis. (p. 67). https://doi.org/10.1002/ange.200803496

Holden, R. J., \& Karsh, B. T. (2010). The Technology Acceptance Model: Its past and its future in health care. Journal of Biomedical Informatics. https://doi.org/10.1016/j.jbi.2009.07.002

$\mathrm{Hu}$, Z., Ding, S., Li, S., Chen, L., \& Yang, S. (2019). Adoption intention of fintech services for bank users: An empirical examination with an extended technology acceptance model. Symmetry. https://doi.org/10.3390/ sym11030340

Lee, S. S., \& Wella, W. (2019). Analisis Technology Acceptance Model Penggunaan E-Learning pada Mahasiswa. Ultima InfoSys. https://doi.org/10.31937/ si.v9i2.913

Nelwan, E. F. (2014). Analisis Faktor-Faktor yang Mempengaruhi Minat Nasabah Menggunakan Layanan BNI New Internet Banking dengan Menggunakan Kerangka Model Penerimaan Teknologi (TAM) (Studi Empiris Terhadap Nasabah BNI Kantor Cabang Utama Manado). Jurnal Riset Bisnis Dan Manajemen.

Ping, R. A. (1993). The effects of satisfaction and structural constraints on retailer exiting, voice, loyalty, opportunism, and neglect. Journal of Retailing, 69(3), 320-352. https:/ / doi.org/10.1016/0022-4359(93)90010-G

Prasada Bangkara, R., \& Mimba, N. putu harta. (2016). Pada minat penggunaan 
internet banking dengan attitude toward using sebagai variabel intervening. E-Jurnal Akuntansi Universitas Udayana.

Rakhmawati, S., \& Isharijadi, I. (2013). Pengaruh Kepercayaan, Persepsi Kegunaan, Persepsi Kemudahan, Dan Persepsi Kenyamanan Terhadap Minat Penggunaan Sistem Internet Banking Pada Nasabah Bank Muamalat Cabang Pembantu Madiun. Assets: Jurnal Akuntansi Dan Pendidikan, 2(2), 71. https://doi.org/10.25273/jap.v2i2.1200

Septiani, R., Handayani, P. W., \& Azzahro, F. (2017). Factors that Affecting Behavioral Intention in Online Transportation Service: Case study of GOJEK. In Procedia Computer Science. https:/ / doi.org/10.1016/j.procs.2017.12.183

Sharma, N., \& Patterson, P. G. (2000). Switching costs, alternative attractiveness and experience as moderators of relationship commitment in professional, consumer services. International Journal of Service Industry Management, 11(5), 470-490. https:/ / doi.org/10.1108/09564230010360182

Silvia. (2015). Pengaruh Personalization, Computer Self Efficacy, Dan Trust Terhadap Perceived Ease of Use Serta Perceived Usefulness Pada Perusahaan Bank DKI Cabang Walikota Jakarta Barat. Jurnal Perpustakaan Universitas Esa Unggul. 12 (50).

Sugiantoro, Y., \& Isharijadi, I. (2015). Pengaruh Personalization, Computer Self Efficacy, Dan Trust Terhadap Perceived Usefullness Pada Pengguna Internet Banking Di Pt. Bank Bri (Persero), Tbk. Cabang Madiun. Assets: Jurnal Akuntansi Dan Pendidikan. https:/ / doi.org/10.25273/jap.v4i1.677

Sugiyono. (2017). MetodePenelitian Kuantitatif, Kualitatif dan R\&D. Bandung: PT Alfabet., 53(9), 1689-1699. https:// doi.org/10.1017/CBO9781107415324.004

Wibowo, S. F., Rosmauli, D., \& Suhud, U. (2015). Pengaruh Persepsi Manfaat, Persepsi Kemudahan, Fitur Layanan, Dan Kepercayaan Terhadap Minat Menggunakan E-Money Card (Studi Pada Pengguna Jasa Commuterline Di Jakarta). JRMSI - Jurnal Riset Manajemen Sains Indonesia. https://doi.org/10.21009/jrmsi.006.1.06

Yousafzai, S. Y., Foxall, G. R., \& Pallister, J. G. (2007). Journal of Modelling in Management Technology acceptance: a meta-analysis of the TAM: Part 1. Journal of Modelling in Management Iss Journal of Modelling in Management Iss Journal of Enterprise Information Management Internet Research.

Yuda, Firska Tiara. (2014). Pengaruh Perceived usefulness dan Perceived Ease of Use Terhadap Minat Perilaku Menggunakan SIM GAJI Dengan Pengalaman Sebagai Variabel Pemoderasi. Digital Repository Universitas Jember.

Zhang, K. Z. K., Lee, M. K. O., Cheung, C. M. K., \& Chen, H. (2009). Understanding the role of gender in bloggers' switching behavior. Decision Support Systems, 47(4), 540-546. https:/ / doi.org/10.1016/j.dss.2009.05.013

Zhou, T. (2012). Examining mobile banking user adoption from the perspectives of trust and flow experience. Information Technology and Management, 13(1), 27-37. https:// doi.org/10.1007/s10799-011-0111-8 